\title{
Symbolic Meanings in the Ritual Speech of Pattomateang Ceremony of Towani Tolotang Community in Ampatita Village, Sidrap Regency, South Sulawesi: An Anthropolinguistic Study
}

\author{
Sitoto, Simon ${ }^{1 *}$, Kamsinah $^{2}$, Astina Akkas ${ }^{3}$ \\ ${ }^{1}$ Faculty of Cultural Sciences, Hasanuddin University \\ ${ }^{2}$ Faculty of Cultural Sciences, Hasanuddin University \\ ${ }^{3}$ Briton English Education, Makassar \\ * Corresponding author. Email: simonsitoto22@gmail.com
}

\begin{abstract}
This study aims to reveal the symbolic meanings and values implied in the ritual speech of Pattomateang ceremony of Towani Tolotang community. The research was conducted in Amparita Village of Sidrap Regency. The informants were the people who knew well the subject matters related to the topic of discussion. The data were obtained through observation, note-taking, and recording which were transcribed and then translated into English. They were analyzed qualitatively descriptively using anthropolinguistic theories to reveal the symbolic meanings and values depicted in Pattomateang ritual ceremony. Based on the data analysis, the research results reveal that the symbolic meanings implied in Pattomateang ceremony are related to the invocation of the community represented by Uwatta or Uwa to God through Dewa Seuwae so that they can inhabit the Linoe (earth) peacefully and prosperously as depicted in some utterances performed by Uwatta or Uwa. Besides, they also imply moral values and local wisdom related to human life. The Atlantis Press Proceedings article template has many predefined paragraph styles for you to use/apply as you write your paper. To format your abstract, use the Microsoft Word template style: [Abstract]. Each paper must include an abstract. Begin the abstract with the title "Abstract" in bold font, followed by a paragraph with normal 10-point font. Do not cite references in the abstract. Please do not place or cite tables and figures in the abstract either.
\end{abstract}

Keywords: symbolic meaning, ritual speech, Amparita community, Pattomateang ritual

\section{INTRODUCTION}

Buginese tribe is one of the biggest ethnic groups in South Sulawesi spreading in several regions such as in Wajo, Bone, Soppeng, Barru, Pinrang, Pare-Pare, Sidrap, Luwu, and Sinjai. In some cases, the cultural ceremonies performed in one region are different from the ones performed in the other regions. In general, the language used in these regions is Buginese language; however, the language used in one region has some differences from the one used in the others as found in words and pronunciations. Similarly, cultural performances and daily habits in one region are quite different from the ones in other regions.

One of the Buginese ethnic groups in South Sulawesi is in Sidrap Regency, especially in Amparita
Village, Tellu Limpoe District i.e. Towani Tolotang community. This community has its cultural activities as performed in marriage ritual ceremony, feasting day as seen in Massempe, Mappenreq Nanre, Tudang Sipulung, and Pattomateang ceremony or Pattomateang.

In conjunction with the given name to the community, i.e. Towani Tolotang, the word Towani is etymologically derived from the word to/tau, meaning people and wani refers to the name of a village. Therefore, Towani means people coming from the village of wani. Meanwhile, Tolotang is derived from the word to/tau, meaning people and lotang means south. Therefore, Tolotang means people coming from the south. Towani Tolotang is a community that has its local wisdom which is descended from their ancestors 
as seen in some ritual ceremonies such as marriage and death ceremonies. Regarding the marriage ceremony performed in Towani Tolotang, Sidrap Regency, there is a little difference from the one performed in the Buginese community in other regions.

The people of Towani Tolotang perform marriage and death ceremonies by following both Islam traditions as performed by Buginese people in general and the one similar to Hinduism ritual. Those ceremonies are not only performed based on the rules in Islam but also preceded by some rituals based on their tradition.

Thus, Towani Tolotang community is an interesting topic to study because this community follows its social system of religious concept. Another thing is that this community performs some of its cultural aspects descended from its ancestors and they have never been changed.

This study aims to reveal one of the ritual performances called Pattomateang ceremony in Towani Tolotang Community in Amparita Village and to reveal the connotative symbolic meanings implied in this ritual containing values and local wisdom implemented in that community. Pattomateang ceremony is performed once a year every January to inaugurate the message from $I$ Pabbere as its ancestor who left a message to his descendants to visit his grave to pray. Therefore, the community members from all over Indonesia come to his grave to pray As this topic concerns observing cultural aspects through the use of language, anthropolinguistic theories become the basis. Linguistic anthropology is the study of the relationship between anthropology, i.e. the study of man and his culture, behaviour, diversity, etc and linguistics, i.e. the study of language as the basis to study man and his cultural aspects. In other words, linguistic anthropology is the study of man and his culture through language analysi [1]. Similarly, Danesi [2] states that the goal of anthropological linguistics is to study languages by obtaining data directly from indigenous society. Furthermore, Duranti [3] introduces three main theoretical aspects that have been developed within linguistic anthropology, namely performance, indexicality, and participation. Performance as opposed to competence concerns with the actual use of a language, i.e. the implementation of knowledge in acts of speaking [3]. Thus, performance is the actual use of language to reveal cultural aspects held in a certain community. Ritual speech is a cultural aspect performed by certain participants through speaking which generally indexes various connotative symbolic meanings based on the context in which they are used. In this connection, this writing is based on Pierce's [1] theory proposing triadic signs.

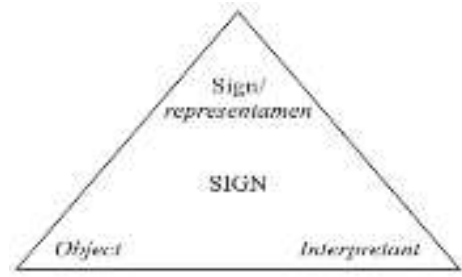

Pierce's (1955): triadic sign

This shows that object as the designatum, denotatum, or referent / signified refers to the icon (a sign that stands for an object similarity with it such as a photograph), index (an indexical sign that points to its object through some connection or contiguity, that is, a co-occurrence in the same context such as personal pronouns or a natural sign like smoke indexing fire), and symbol (a sign that refers to its object-based on convention like red light symbolizing stop). The symbol used here is concerning connotation under convention used by a certain community [1].

In connection with this, the connotative meaning of a word or phrase is the secondary meaning of what it is associated with within the sense that it can be something suggested or implied by a word or thing, and not something which is explicitly named or described. Connotative meaning is the communicative value of an expression based on what it refers to, over, and above its pure concept [4]. For example, a rose is indeed a type of flower. It is also associated with romantic love, beauty and even special days, like Valentine Day and anniversaries. Therefore, a symbol is a general name or description which signifies its object using an association of idea or habitual connection between the name and the character signified. Connotations go beyond the literal meanings to what is thought and felt when a word is heard or seen. This type of meaning is related to symbols in particular metaphors. All symbols involve three elements namely the symbol itself, one or more referents, and the relationship between symbols and referents. These three things are the basis for all symbolic meanings [5]. Thus, connotative meaning is not separated from symbolic meaning. In this writing, Pattomateang ceremony is a cultural aspect performed by the master (Uwatta or Uwa) of the ritual speech through speaking to communicate with God through Dewata Seuwae. This kind of speech contains many symbolic meanings and values that should be interpreted connotatively.

Thus, concerning the above ideas, this writing is going to answer the question on "What are the symbolic meanings and values implied in the ritual speech of Pattomateang ceremony in Towani Tolotang community?"

This research is expected to be useful for the readers and to those who are interested in observing the cultural aspects of the Buginese community especially 
the one in Amparita Village, Sidrap Regency and to give a contribution to further researches related to this topic.

\section{METHODOLOGY}

The research was conducted in Amparita Village in Tellu Limpoe District of Sidrap Regency, South Sulawesi Province concerning one of the cultural aspects of Towani Tolotang Community particularly a ritual speech in a death ceremony called Pattomateang ceremony.

The informants were the community leaders and others who knew well the Mabbolo ritual speech of Pattomateang ceremony. The Mabbolo ritual speech performed in this ceremony consists of 34 utterances in the form of clauses but only six utterances were taken as the sample selected purposively fulfilling the criteria needed. Since this research was an ethnographic study, the method used was a direct observation called participative observation in which the researcher was directly involved in obtaining the data. The needed data were collected through observation, interview, notetaking, and recording. They were analyzed using a qualitative descriptive approach.

\section{DISCUSSION}

In Pattomateang Ceremony, there are some rituals performed by Towani Tolotang Community. First, the people come to a place of worship to perform a ritual led by Uwatta. After that, the people should do an obligation to visit the grave of I Pabbere at Perrinyameng without using footwear. In this ritual procession, the community uses betel leaves to coat the corpse. Another procession is Mappenreq Nanre in which people should bring some food to I Pabbere's grave. Besides, Tudang Sipulung is also a procession performed in which people sit together in one place to perform a ritual. Those rituals are led by Uwatta who reads Lontaraq as the holy book. Uwatta who performs the ritual pours Minyak Bau (perfumed oil) into I Pabbere, I Goliga, and other ancestors' graves to bless them. This is the ritual called Pattomateang. The oil used is a mixture of coconut oil and teak shoots. Thus, the performance of Pattomateang ceremony is one of the obligations for Towani Tolotang people to do because this is a message descended by their ancestors to visit their grave once a year so that they can live peacefully in their life both in the world called Linoe and hereafter.

The data of Mabbolo ritual speech performed in Pattomateang ceremony are presented in the following analysis consisting of six utterances.

a. O Puwang passalama'i toriampiku

O Puwang pa-salama $i \quad$ to riampi $\quad-k u$

Oh God pref save people in control my
'Oh God do save the people in my control'

This utterance (line 4) is an invocation as indicated by the word passalama' $i$. This word consists of salama' - an adjective, meaning safe, pa- as a prefix forming a verb - passalama', meaning to save and suffix -i referring to shepherds that symbolize people. Thus, this word carries an illocutionary force [6] of demanding or commanding in which Uwatta or Uwa asks God to save his shepherd. Meanwhile, suffix pronoun $k u$ in toriampiku meaning possessive my refers to Uwatta who performs this ritual speech. Connotatively, the word to-riampi (shepherds) symbolizes all people or families in Towani Tolotang Village coming to the ritual ceremony whom Uwatta asks God to save. Therefore, the utterance $\mathrm{O}$ pawang passalama' $i$ toriampiku connotatively symbolically implies 'Oh God does save my people. Uwatta as the leader of the community always guards and prays for his people by asking the Creator (God) to protect and provide them with salvation to inhabit the world/earth and the hereafter safely, peacefully, and prosperously as indicated in line 5 nasalama' ri lino lettu ri akhera meaning "so that they are safe on the earth until hereafter". It is repeated in line 8 O Puwang ta passamala'i meaning "Oh God, please save them" to emphasize his expectation or invocation.

Such as an invocation seems to be based on Uwatta's anxiety looking at the condition in this world/ earth called Linoe in Buginese language at present in which from day to day people experience many problems such as thefts, violence, kidnappings, murders, juvenile delinquencies, diseases, and others disasters. This is contrary to the original concept of the earth given by the ancestors who called it Linoe. For them, the earth or Linoe (clarity or purity) is a place where people should clarify and purify their souls and customs so that they can live safely and peacefully. This kind of concept is similar to the one given by Torajan ancestors who also call it Lino in Torajan language. If this word is given prefix ma-, it forms an adjective, malino meaning to be quiet, clear, pure, or limpid. Therefore, Lino must be a quiet, peaceful, safe, and calm place to inhabit. It is a place to live serenely. It should not have been a marota' (rota') or malutu (lutu) place, i.e. a muddy, dirty, noisy place as what is happening nowadays because of various uncontrolled social, political, economic, legal, cultural, and environmental problems and others as mentioned previously caused by the irresponsible humans themselves that ruin the existence of the earth changing from a Linoe/Malino place to a rota'/marota or lutu/malutu place).

\section{b. Sawe buwana ajukajung riyanre, tenga nango}

sawe buwa na ajukajung ri yanre tenga nango

Develop fruits their trees be/are eaten no insect

'Fruits from their trees are eaten without any insects' 
Ajukajung "trees" in this line (16) are compared metaphorically with people in the sense that trees can flourish and produce good fruits if they are not attacked by any pests such as nango, a very stinking small insect that very frequently attacks plants. This connotatively symbolizes that people can live healthily if they do not suffer from any diseases. Thus, the people in this community can cultivate their land well and live prosperously if they are not disturbed by any crimes, violence, and environmental and other social problems. This line also indicates an invocation in which Uwatta always prays to God through Dewata Seuwae for the safety of his people.

c. Na rilegari calikerra' na langi'e

$\mathrm{Na}$ rilegari calikerra' na langi' e
so that be opened chain its sky article

'So that the chain of the sky can be opened'

In this context (line 21), the word calikerra means "chain". In the past, it was said that God closed the sky even the earth for the people as the punishment for Sawerigading. Therefore, Uwatta asks God to open the sky and bestow continuous blessing and fortune to his people. In this situation, the chain is the symbol of fortune. Chain is a series of things connected to form a continuation of an unending end. Thus, fortune is symbolized with a chain meaning that people's fortune/benefit is expected to continue as a chain throughout their life on earth. People expect that all goods will be given to them and their families. In contrast, all crimes are expected not to happen to them. Uwatta asks Dewata Seuwae to open the door of fortune for them such as getting adequate agricultural products, being successful in other livelihoods, getting a comfortable place to dwell, being given good health and prosperity, having a harmonious relationship with spouse, and having a blessed family. Those also constitute invocations raised to God through Dewata Seuwae so that all members of each family are always given a good fortune to live safely and prosperously in their family.

\section{d. O Nurung! Engkai menye ulau na puang mu}

O Nurung! Engkai menye ulau na puang mu

O Nurung! There is here gold His God 2nd your

'O Nurung, here is your God's gold from the sky'

In this line (28), ulau means a very shiny valuable stone or gold which is very similar to batu giok (jade). Contextually, valuable stone or gold (ulau) provided by God is the symbol of the continuation of a good generation. As a batu giok (jade) never fades and keeps on glowing and it is so valuable that the people always keep it well, the community should always look after the continuation of a good generation from time to time to give light like batu giok and be beneficial for others.
This line is also related to the existence of a stone/rocky mountain in this area which is very valuable for the local people where they always mine for various purposes such as to mine batu giok (jade). Although it has been being mined for a long time, the excavated materials have never run out. In this context, the mountain stone provided by God is also a symbol of the continuation of generation. Thus, both of them symbolize that Uwatta always prays to God to bestow goodness for the continuation of a good generation and for the sake of preservation of good cultural norms and local wisdom in the future like both the stone mountain that has never stopped providing mining materials for the local people and batu giok (jade) that always shines and gives happiness for the owner.

In Towani Tolotang community, parents should look after their children by teaching them goodness based on their beliefs. In each family, parents should have a strong commitment as they are entrusted by God (Dewata Seuwae) to take care of their children in every family under the guidance and protection of Dewata Seuwae. Parents should always provide well-guidance for their children and direct them to the right way of life by praying for them as indicated in lagaligo expression stating that Tomatowanna Jellokangngi laleng ana'na mangalo ri puang'el Dewata Seuwae means 'their parents are indicating a good way by praying to God (Dewata Seuwae"). It can be seen in every ritual ceremony in which there are a lot of children joining the ritual to pray to God through Dewata Seuwae so that they can be given the virtue to live peacefully and safely in the world and afterlife.

e. Bessi tone' asenna

Bessi tone' asen -na

Iron hard name his

'His name is hard iron'

In this context (line 30), bessi means 'iron' and tone' means 'hard' or 'strong'. Tone' itself is the name of a part of a tree that relates the root and the stem. This part of a tree is the strongest one as it combines the two parts to grow strong. Therefore, in this context, Bessi tone' is a symbol of strength and courage. This is not only the symbol of a strong body physically but also the symbol of a strong spirit in the sense that the people in that community have a strong principle to fight for the truth, policy, honesty, and kindness for the benefit of others. To obtain all such goodness, Uwatta always pray to God to give his people health and strength like iron and tone' so that they can survive because of their ability to overcome various problems faced in their life.

Besides, it is also a symbol of the strong determination of the Tolotang people to develop and maintain their specific cultural values as implied in the teaching of Hinduism descended from their ancestors in 
which they have made an agreement that they must not break as they have indebted to them. They have promised not to leave the teaching, but they have to treat and preserve it from generation to generation. Bessi tone' is also a symbol of courage referring to Buginese people's spirit to have a high fighting spirit as depicted in maritime culture in which someone should not easily give up to his/her fate as the Buginese proverb says: 'sekali layar terkembang pantang biduk surut ke pantai' 'once the sail expands, the dipper never recedes/goes back to the beach'.

\section{f. Namattedde wae massolo' ri passapo e'}

$\mathrm{Na}$ - mattedde' wae massoloq ri passapo $e^{\prime}$
So that strong water flow in body it

'So that the water strongly flows in his body/soul'

Contextually, (line 34), Uwatta prays to God through Dewata Seuwae for his people in order that they can have a strong flowing water in their body. This means that with a strong flowing water people can clarify and purify both their body and their soul from all bad things to have a good character so that God can bestow them goodness. In this context, water symbolizes clarity and purity.

For the people of Towani Tolotang community in particular and Buginese people in general, human body is called Watangkale. According to their ancestors, Watangkale is created from four basic elements namely soil, water, fire, and wind. Soil is the symbol of patience and firmness; water is the symbol of calmness, clarity, and purity; fire is the symbol of emotion and courage, and wind is the symbol of inconsistent nature. In this ritual, wae 'water' is the only element given attention since it is related to purity of someone's body and soul in which someone is called a holy man if he/she has a calmness related to character/attitude/behaviour (kind, patient, indulgent, honest), clarity or cleanliness related to his/her appearance/body (nice, neat, simple) and purity related to his/her soul or spirit (holy, devout, godly)

As the closing line of all utterances in the ritual speech, line 34 gives emphasis that whatever people have as having been discussed previously such as having a good health, wealth, strength, good fortune, etc. will all be in vain if they have a bad character. Therefore, to have a good character that greatly determines the value of their life, the Towani Tolotang community in particular and the people in general should present 'strong flowing water' (mattedde wae massalo') in their body and soul for the sake of selfclarity and self-purity to inhabit the earth 'lino' safely and peacefully. This line (34) is closely related to line 4 discussed at the beginning in that the world/earth can only be clarified and purified if the people living in/on it can clarify and purify themselves and their customs to have a good character.

In short, such a ritual speech having been discussed in advance implies many values as the local wisdom concerning with humanity concerning Creator/God and surroundings that the people should implement in their live, preserve, and descend them from generation to generation. Thus, this short writing can be a source of inspiration for the stakeholders to design oral traditionbased subjects containing values as the local wisdom that also imply in other various types of ritual speeches and oral traditions.

\section{CONCLUSION}

Based on the data analysis, it can be concluded that Pattomateang ceremony is one of the death ceremonies held once a year by the people of Towani Tolotang community in Amparita village, Sidrap Regency. Pattomateang ceremony has a ritual speech which is performed by Uwatta, the leader of the ritual ceremony. The ritual speech contains various types of connotative symbolic meanings and values as the invocation of the community represented by Uwatta to God through Dewata Seuwae to inhabit the earth (Lino) safely, peacefully, and prosperously. Those symbols contain values and local wisdom that are strongly held by the people in that community such as (a) religious values, i.e the invocation to God to ask for protection from all types of dangers, have prosperity in utilizing environment/land and good fortune, (b) humanity values such as having harmony in the family, maintaining selfpurity from all misuse of worldly possessions that can damage their relationship with God (Dewata Seuwae), (c) spiritual values such as having both physical and spiritual strength, courage, and power to never giving up in the struggle of life as symbolized with bessi tone', and having a good character as symbolized with mattedde'wae massolo'.

Thus, it is suggested that Pattomateang ceremony as one of the cultural heritages of Buginese ancestors especially the community in Amparita Village be descended from generation to generation for the sake of its preservation. Besides that, it is suggested that further researches be conducted to observe more on the figurative language used in the ritual speech of Pattomateang ceremony to reveal more on the values and local wisdom implied in such a ritual speech implemented in the life of Towani Tolotang community.

\section{AUTHORS' CONTRIBUTIONS}

The second and the third authors provide great support in terms of spirit and valuable ideas presented in this writing. 


\section{ACKNOWLEDGMENTS}

The writer would like to express his gratitude to Prosiding ATLANTIS for a great opportunity given to the writer where this writing is published. A great thank is also directed to his teammates for very valuable ideas and good cooperation in writing this paper as well as colleagues at the English Department, Faculty of Cultural Sciences, Hasanuddin University for their support. Last but not least, the writer would also like to thank his wife and daughters for their support.

\section{REFERENCES}

[1] Ahearn, Laura M. Living Language: An Introduction to Linguistic Anthropology. John Wiley \& Sons, Ltd, 2012.

[2] Danesi, Marcel. A Basic course in Anthropological Linguistics. Cambridge: Cambridge University Press, 2004.

[3] Duranti, Alessandro (1997). Linguistic Anthropology. Cambridge: Cambridge University Press, 1997.

[4] Zdravkovic, Nikola. The Meaning of Meaning: Leech's Seven Types of Meaning in Comparison to Palmers and Lyons' Approaches. Erlangen: EMLex, 2017.

[5] Sobur, Alex. Semiotika Komunikasi. Bandung: P.T. Remaja Rosdakarya, 2004.

[6] Cruse, Alan. Meaning in Language. An Introduction to Semantics and Pragmatics. Oxford: Oxford University Press, 2000.

\section{APPENDIX:}

The transcription of Mabbolo ritual speech and the translation:

1) Bissu rilangi remmang rilangi Bissu ri- langi remmang ri- langi Bissu Prep. sky wish Prep. Sky "Bissu in the sky, wish your blessing from the sky"

2) U sompai bitinglangi,

U sompai biting langi

I worship the sky

"I worship the sky"

3) Madduwa palekka ri pertiwi

Madduwa palek $\mathrm{ka}$ ri pertiwi

both palms my Prep. earth

"With my both hands on earth"

4) O pawang passalamai toriampiku

O pawang pa salama $-i$ toriampi $k u$ Oh God please save they shepherd my
"Oh God save my shepherd"

5) nasalama rilino lettu ri akhera'

na- salama ri-lino lettu ri- akhera' sothat safe prep.World until Prep. afterlife "so that the world is safe until afterlife"

6) Namasempo dalle madeceng onroang $\mathrm{Na}$ - masempo dalle' ma deceng onroang So that easy/cheap fortune so that well place

"So that it is easy to get good fortune and comfortable place"

7) rilinona lettu rilino paimeng

ri lino na lettu rilino paimeng Prep. World His/God until Prep. world afterlife

"in the God's world until afterlife"

8) O pawang, tapasalama' $i$

O pawang ta pa salama $i$

Oh God please save them

"Oh God please save them"

9) Tana iya madecennge riyonroi mabbola,

Tana iya ma deceng -e ri-yonroi ma- bola soil is prep.good Suf. Prep.stay Prep. house "The land which is good to stay"

10) Madaceng ritu riyonroiwi sau ininnawa.

Ma daceng ritu ri yonroi wi sau ininnawa.

Prep. Good for Prep. stay it fatigue "Good for take a rest"

11) Porennui i sawe asena,

Porennui $i$ sawe ase na

Hope they develop ricefield their "The expection made by Uwatta to God for fertile ricefield"

12) Sawe i tau tabbeqe,

Sawe i tau tabbeqe

Develop their people

"Their people are developing"

13) sawe tedonnge, sawe olokoloe, sawe tedong $e$ sawe olokolo $e$ develop bulls it develop animals it "developing bulls, developing animals"

14) tennatuju baweng sai atuo tuona tau tebbeqe, te-natuju baweng sai a tиo tuo -na tau tebbeqe

Pref. Neg happen disease Pref. life life their people

"their life are not get disease"

15) Sawe taneng tanennge, 
sawe taneng taneng - $e$

develop plant plant it

"plants to be fertile"

16) sawe buwana ajukajung riyanre, tennganango.

sawe buwa -na ajukajung ri- yanre tennga nango

Develop fruits their trees Prep. eaten

Pref.Neg insect.

"Fruits from their tree which is eaten also to be fertile without insect

17) Porennu i a' dapemmu

Porennu $i$ a' dape mu

Hope they Pref. forgiveness your

"They are expecting your forgiveness.

18) A'masei'ka pakule'a

A' masei ka pakule' a

Pref. blessings my effort Suf.

"Blessing all of my effort"

19) Were ka' a' watannge tuwo rilino e

Were $k a$ ' a' watang e tuwo ri lino $e$ Give me Pref. strength it life Prep world it

20) A'pangara o sangka batara

A' pangara o sangkabatara

Pref. Command oh God

"Oh God please give your command"

21) Nari' legari calikerra'na langi'e nari' legari calikerra' na langi' $e$ so that opened chain it sky it. "So that the chain of the sky can be opened"

22) Narireddu te'ma gonratung

$\mathrm{Na}$ - rireddu te'ma gonratung

In order to lift crossbar thunderbolt

"In order to lift the sealing"

23) Pa'sulu'na tange' batara rakile'e

$P a$ 'sulu - na tange' batara rakile' $e$

Pref. sealing it gate God firmament it

"Of firmament gate like thunderbolt"

24) Risenne' dua langi'e

Risenne' dua langi' e

Cloven two sky it

"Split the sky"

25) Ripatingoang pitung lapi batara'e $R i$-patingo -ang pitung lapi batara' $e$ Pref.stretched Suf. seven layer God it "So that seven layers of firmament can be stretched out
26) O butta kuonjok, palewangang tallasakku $O$ butta $k u$ - onjok palewangang tallasa $-k u$

O land I step get it straight way of life my

"O land that I step, please make easy the way of my life"

27) Eranga mange ri kaminang mateknea Erang nga mange rikaminang mateknea Take me here Prep. place better "Take me to the better place"

28) O nurung engkai menyeulauna puang mu

$O$ Nurung engkai menyeulau -na puang $m u$

O Nurung here stone/gold His God your

"O Nurung, here is your God's stone/gold from the sky

29) Pole lolang ri boting langiq lisu mancaji bessi

Pole lolang ri boting langiq lisu mancaji bessi

From come in above sky return good iron

"From the sky returning well to be iron"

30) Bessi tone' asenna

Bessi tone' asen -na

Iron hard name his

"His name is hard iron"

31) bessi iya monroe mabenni rinyawaku bessi iya monroe mabenni ri nyawa $k u$

iron which stay Prep. soul my

"The iron which stays in my soul"

32) Assuko muajjepperika

Assuko mu- ajjepperi $k a$

Come you give me

"Please you come and give me"

33) Namallise' bessi watangkaleku

$\mathrm{Na}$ - mallise' bessi watang kale $\mathrm{ku}$ in order to fill iron body my "A strength like an iron in my body"

34) Namattedde' wae massoloq ripassapo e' $\mathrm{Na}$ - mattedde' wae massoloq ri passapo e' So that strong/hard water flew in body it "So that the water strongly flows in his /body soul" 